\title{
THE REPELLENCY EFFECTS OF THREE PLANT ESSENTIAL OILS AGAINST THE TWO-SPOTTED SPIDER MITE TETRANYCHUS URTICAE
}

\author{
YEŞILAYER, A. \\ Plant Protection Department, Agricultural Faculty, Gaziosmanpasa University \\ 60216 Tokat, Turkey \\ (e-mail: ayse.yesilayer@gop.edu.tr) \\ (Received 26 $6^{\text {th }}$ Jun 2018; accepted $31^{\text {st }}$ Aug 2018)
}

\begin{abstract}
Many spider mite species are polyphagous and live together. They are significantly harmful pests for agricultural crops. Acaricides and insecticides are commonly used to control T. urticae. Spider mites can rapidly develop resistance to pesticides. Organic control may be considered as an alternative and environment-friendly approach. Three native plants essential oils were isolated by hydrodistillation technique hydro distillation in a Clevenger type apparatus. In this study, Thymbra spicata L. (Labiatae), Laurus nobilis L. (Lauraceae) and Myrtus communis L. (Myrtaceae) plants have been tested for their essential oil's repellency effect. Essential oils of these three plants were compared for $48 \mathrm{~h}$ at four different doses $(0.1,0.5,1$ and $2 \mathrm{ml} / \mathrm{l})$. We observed repellency effect all does and for all essential oils, whereas M. communis was proven to be a stronger repellent compared to L. nobilis at $2 \mathrm{ml} / \mathrm{l}$.
\end{abstract}

Keywords: control, essential oil, repellency effect, Tetranychus urticae, Tokat, Turkey

\section{Introduction}

The two-spotted spider mites, Tetranychus urticae Koch. (Acarina: Tetranychidae), are about $0.5 \mathrm{~mm}$ in size, with reddish or greenish body color. The adult female body bears 12 pairs of dorsal seta. Two-spotted spider mites (TSSM) were initially described as a European species by Tuttle and Baker in 1968. T. urticae is a significant proliferous polyphagous pest, commonly controlled by pesticides in Turkey and other countries. This mite has more than 1200 known host plants (Zhang, 2003). Pesticides pose serious risks for the environment, non-target-organisms and also human life. Tetranychidae has developed resistance against 80 different acaricides to date (Darp, 2004; Miresmailli et al., 2006; Vanpottelberge et al., 2009). T. urticae has developed resistance to many insecticides and acaricides (Ay and Gürkan, 2005; Dermauw et al., 2013). Eventually, its control has become problematic in many regions of the world. Several researchers have focused on alternative methods to overcome the negative impacts of conventional pesticides. Essential oils and plant extracts are among the alternative methods against pests and spider mites. Plant essential oils have toxic effects on pests through contact, ingestion and fumigation; in addition, plant essential oils or their constituents have significant behavioral effects on pests, especially as repellents (Akhtar et al., 2010). Another study investigated repellency effects of plant extracts obtained from weeds and essential oils of 53 different plants on T. urticae (Kawka and Tomczyk, 2002). The use of plant extracts and essential oils in pest control could be an effective alternative compared to pesticides. Essential oils and their contents such as terpenoids, alkaloids and flavonoids are effective in pest control (Grodnitzky and Coats, 2002). EOs are used antibacterial, antifungal and insecticidal (Chang and Cheng, 2002). Furthermore, plant essential oils have minimal direct and/or indirect effect on predators or the ecosystem (Isman, 2006). Black thyme (Tthymus spicata) grows wild in some Eastern 
Mediterranean countries and Turkey (Kizil, 2010); its essential oil contains 60-80\% of carvacrole. It is belongs to the Lamiaceae family. Thyme has been studied as repellents (Rajkumar and Jebanesan, 2005). Laurus nobilis is also a major source of essential oil and its leaf essential oil was reported to be rich in 1.8-cineole (Baydar, 2009). L. nobilis is a important plant of used in foods, drugs, and cosmetics. Laurus leaves and essential oils are used for antimicrobial and insecticidal activities (Patrakar et al., 2012). Myrtus communis (myrtle) is grows wild and cultivated. It is widespread throughout the Mediterrian region of Anatoloia-Turkey. Myrtus leaves and fruit of the plant contain mirtenol, cineol and terpenes. The main constituents of $M$. communis oil are 1.8-cineole, myrtenyl acetate, myrtenol and limonene (Traveset et al., 2001). The myrtle essential oil observed toxicity fumigation of lepidoptera and coleoptera species (Ayvaz et al., 2010; Tayoub et al., 2012).

This article reports repellency effects of essential oils obtained from flowers, stems and leaves of $T$. spicata, L. nobilis and M. communis against two-spotted spider mites, and positions them as an alternative to pesticides.

\section{Material and methods}

\section{Mites culture}

Two-spotted spider mites were obtained from a colony maintained at the Plant Protection Department, Tokat Gaziosmanpaşa University (GOP), Turkey. Mites were grown in a climate chamber at $26 \pm 1{ }^{\circ} \mathrm{C}, 60-80 \%$ of relative humidity (RH) and $16 \mathrm{~h}$ of light and $8 \mathrm{~h}$ of dark (LD) photoperiod.

\section{Material collection and processing}

T. spicata, L. nobilis and M. communis were collected from around the campus area of GOP University during the summer season in June-August 2016 (Location 40.3339, 36.4769). Fresh plant parts were air-dried in the shade at room temperature and then grounded. Essential oils were extracted from a $100 \mathrm{~g}$ mixture of stems, flowers and leaves using a Clevenger-type apparatus within $2 \mathrm{~h}$. The essential oils were later stored in sealed vials at $4{ }^{\circ} \mathrm{C}$ until the time of analyses (as previously performed by Cosimi et al., 2009).

\section{Repellency effect}

During the trial, same age ten adult female mites were transferred into $3 \mathrm{~cm}$ bean leaf disks as nutriment and then placed in $9 \mathrm{~cm}$ Petri dishes. We tested four different concentrations $(0.1,0.5,1$ and $2 \mathrm{ml} / \mathrm{l})$ of essential oils of $T$. spicata, L. nobilis and $M$. communis. They were dissolved in water containing $0.3 \%$ Tween 20 and were diluted to the targeted doses. Leaf discs (30 mm diameter) were cut from $P$. vulgaris leaves. In the repellency assay, half of leaf discs were immersed in water containing $0.3 \%$ Tween 20 , which served as control and the other half of the leaf discs were immersed in each essential oil solution for $20 \mathrm{~s}$ before drying in room temperature for $30 \mathrm{~s}$. Afterwards, leaf discs were put in Petri dishes; ten adult females (1-2 day old) of T. urticae were placed on the center of each leaf disc. Cotton saturated with water was added in the Petri dishes in order to maintain the leaf turgor and avoid escape of mites.

Plates were then sealed with parafilm to prevent any loss of essential oils. Each treatment was repeated for three times. The number of mites on treated leaves (half of 
the leaf) and untreated leaves (the other half of the leaf) were counted at 2, 24 and $48 \mathrm{~h}$ post treatment respectively and repellency index was calculated by $R I=(C-T / C+T)$ $\times 100$ (Pascual-Villalobos and Robledo, 1998). In this formula RI stands for repellency index, $\mathrm{T}$ is the number of mites in treatment group and $\mathrm{C}$ is the number of mites in the control group.

\section{Phytotoxicty test}

Based on a study by Miresmailli and Isman (2006), essential oils of three test plants were tested on rose shoots (Rosa damascena Mill) using 1\% solution (300 ml) consisting of essential oil, distilled water and Triton X. Each plant's essential oil (30 ml solution) was sprayed on rose shoots by using a handle sprayer, while control rose shoots remained unsprayed. Shoots were prepared in a glass flask filled with tap water $(500 \mathrm{ml})$ under laboratory condition maintained at $26 \pm 1^{\circ} \mathrm{C}$ and $16 \mathrm{~h}$ of light and $8 \mathrm{~h}$ of dark (LD) photoperiod. Results were recorded after a treatment 24 using a scale between 0 to 4 . Each treatment was replicated three times.

\section{Data analysis}

The repellency effects were analyzed by one-way analysis of variance (ANOVA) and significant differences between mean values were found by Tukey test using SPSS version 19.0. P-value $<0.05$ was regarded as a significant difference.

\section{Results and discussion}

The repellent activity of three different plant essential oils tested at various concentrations after 2, 24 and $48 \mathrm{~h}$ post exposure period are presented in Table 1. T. spicata was found to have the lowest repellency effect at $49.9 \%$ in $2 \mathrm{~h}$ and $45.8 \%$ after 24 and $48 \mathrm{~h}$. We also observed that the repellency effects of essential oils on adult mites would increase with time regardless of the concentration level.

Table 1. Repellency effects of three plants' essential oil on Tetranychus urticae

\begin{tabular}{c|c|c|c|c}
\hline \multirow{2}{*}{ Time (h) } & \multirow{2}{*}{ Concentration (ml/I) } & \multicolumn{3}{|c}{ Repellency effect (\% \pm SE) } \\
\cline { 2 - 5 } & & Laurus nobilis & Myrtus communis & Thymbra spicata \\
\hline \multirow{3}{*}{2} & 0.1 & $76.9 \pm 11.98 \mathrm{a}$ & $79.16 \pm 12.50 \mathrm{a}$ & $49.99 \pm 08.90 \mathrm{a}$ \\
& 0.5 & $75.00 \pm 10.44 \mathrm{a}$ & $79.16 \pm 16.59 \mathrm{a}$ & $70.83 \pm 11.67 \mathrm{a}$ \\
& 1 & $80.95 \pm 12.29 \mathrm{a}$ & $83.33 \pm 06.29 \mathrm{a}$ & $79.16 \pm 10.79 \mathrm{a}$ \\
& 2 & $87.50 \pm 8.76 \mathrm{a}$ & $95.83 \pm 04.16 \mathrm{~b}$ & $83.33 \pm 08.90 \mathrm{a}$ \\
\hline \multirow{3}{*}{24} & 0.1 & $58.33 \pm 08.33 \mathrm{a}$ & $79.16 \pm 12.50 \mathrm{a}$ & $45.83 \pm 06.09 \mathrm{a}$ \\
& 0.5 & $66.66 \pm 08.90 \mathrm{a}$ & $75.00 \pm 12.19 \mathrm{ab}$ & $75.01 \pm 10.44 \mathrm{ab}$ \\
& 1 & $70.83 \pm 07.55 \mathrm{a}$ & $83.33 \pm 06.29 \mathrm{a}$ & $79.16 \pm 08.76 \mathrm{~b}$ \\
48 & 2 & $79.16 \pm 08.76 \mathrm{~b}$ & $91.66 \pm 05.45 \mathrm{~b}$ & $83.33 \pm 06.29 \mathrm{a}$ \\
\hline \multirow{3}{*}{4} & 0.1 & $50.00 \pm 06.29 \mathrm{a}$ & $66.66 \pm 08.90 \mathrm{a}$ & $45.83 \pm 06.09 \mathrm{a}$ \\
& 0.5 & $58.33 \pm 08.33 \mathrm{ab}$ & $70.83 \pm 13.26 \mathrm{a}$ & $75.00 \pm 10.44 \mathrm{ab}$ \\
& 1 & $66.66 \pm 06.29 \mathrm{ab}$ & $79.16 \pm 06.09 \mathrm{a}$ & $79.16 \pm 08.76 \mathrm{ab}$ \\
& 2 & $75.00 \pm 04.35 \mathrm{a}$ & $95.83 \pm 11.78 \mathrm{~b}$ & $91.66 \pm 05.45 \mathrm{~b}$ \\
\hline
\end{tabular}

Different letters within the same rows and columns indicate significant differences between essential oils and treatment concentrations, respectively $(\mathrm{p} \leq 0.05)$ (Tukey test) 
24-h repellency effects of $L$. nobilis and $M$. communis at $0.5 \mathrm{ml} / 1$ concentration on adult females of two-spotted spider mites were recorded as $66.6 \%$ and $75 \%$ respectively, which was statically significant $(\mathrm{P}<0.05)$. The repellency effect of $T$. spicata at the lowest concentration $(0.1 \mathrm{ml} / \mathrm{l})$ was found to be lower than L. nobilis and M. communis at the end of 2,24 and $48 \mathrm{~h}$ and there is no difference statistically. In addition, no significant difference was found between the repellency effects at $2 \mathrm{~h}$ and $48 \mathrm{~h}$, when applying $0.1 \mathrm{ml} / 1$ concentration. At $2 \mathrm{~h}$, in all three plant essential oil treatments, the effect of 0.1 and $2 \mathrm{ml} / \mathrm{l}$ concentrations were statistically within the same range. The highest repellency effects were observed at the and of $48 \mathrm{~h}$ with $M$. communis and T. spicata essential oil on T. urticae adults as $95.8 \%$ and $91.6 \%$ respectively. Furthermore, the highest repellency effect on adult mites identified as $95.8 \%$ with $2 \mathrm{ml} / 1$ concentration of $M$. communis at the 48 was found to be statistically different from other groups $(\mathrm{F}=01.50$, d.f. $=3, \mathrm{P}<0.05)$. Regardless of duration, the repellency effects of all three tested essential oils on $T$. urticae adults changed with the changing concentration. Eventually, $M$. communis essential oil was observed to have highest repellency effects as compared to other test plant essential oils on T. urticae in 24 and $48 \mathrm{~h}$ exposure $(\mathrm{P}<0.05)$.

Essential oils contain several biochemicals including acids, alcohols, aldehydes, ketones, esters, phenols, terpenes and sesquiter penes. Essential oils are used as antifeedant, antiviral, acaricidal, antimicrobial, antioxidant, antifungal, contact and repellent (Isman, 2000, 2006). In this study, we demonstrated repellency effects of essential oils from three plants belonging to Lamiaceae family against two-spotted spider mite. There is no observed any phytotoxic effect on bean plants.

Previously, different concentrations of essential oils from 14 species of Lamiaceae were shown to cause mortality and induce repellency in adult females of the carmine spider mite, T. cinnabarinus. (Mansour et al., 1986). Other studies also confirm repellency effect of $M$. communis essential oil against two spotted spider mites (ElZemmity et al., 2006). In another repellency effect study, four different concentrations of rose essential oil, geraniol and citronellol were applied to T. urticae and results confirmed repellency effects of essential oils on the mites (Yorulmaz-Salman and Erbaş, 2014). In a repellency trial on T. urticae with essential oils of Origanum vulgare L, Micromeria fruticosa L. And Nepeta racemosa L. of the Lamiacea (mint) family, highest motalily rate was observed at $2 \mu 1 / 1$ concetration, and it also increased with time. (Çalmaşur et al., 2006). Another study in greenhouse conditions with essential oils obtained from Cuminum cyminum and Origanum syriacum var bevanii revelaed fumigant effects on T. cinnabarinus and Aphis gossypii (Tuni and Sahinkaya, 1998).

\section{Conclusion}

In conclusion $M$. communis essential oil showed stronger repellency effect on TSSM adults at the highest concentration $(2 \mathrm{ml} / \mathrm{l})$ in comparison to L. nobilis and T. spicata essential oils. We concluded that all three plant essential oils can be used to control $T$. urticae. The repellency effects of $T$. spicata, L. nobilis and $M$. communis essential oils on TSSM adults in all concentrations increased with time. However, it is necessary to perform experiments with these three plant essential oils under the greenhouse conditions and compare results with laboratory results. As a final note, at given concentrations, the tested essential oils were not detected to have any phytotoxic effect on the plants. 
Acknowledgements. We are grateful to Prof. Dr. İzzet Kadığlu (Tokat GOP Univ., Agricultural Fac. of Plant Protection Dept. Turkey) for providing us with the plant specimens.

\section{REFERENCES}

[1] Akhtar, Y., Yu, Y., Isman, M. B., Plettner, E. (2010): Dialkoxybenzene and dialkoxyallylbenzene feeding and oviposition deterrents against the cabbage looper, Trichoplusia ni: potential insect behavior control agents. - Journal of Agricultural Food and Chemistry 58(8): 4983-4991.

[2] Ay, R., Gürkan, M. O. (2005): Resistance to bifenthrin and resistance mechanisms of different strains of the two-spotted spider mite (Tetranychus urticae) from Turkey. Phytoparasitica 33(3): 237-244.

[3] Ayvaz, A., Sagdıç, O., Karaborklu, S., Özturk, I. (2010): Insecticidal activity of the essential oils from different plants against three stored-product insects. - Journal of Insect Science 10(21): 13.

[4] Baydar, H. (2009): Tibbi ve Aromatik Bitkiler Bilmi ve Teknolojisi. - Süleyman Demirel Üniversitesi Ziraat Fakültesi Yayınlar1 Isparta 51: 234-235.

[5] Çalmaşur, O., Aslan, I., Sahin, F. (2006): Insecticidal and acaricidal effect of three Lamiaceae plant essential oils against Tetranychus urticae Koch and Bemisia tabaci Genn. - Indian Crops Production 23: 140-146.

[6] Chang, S. T., Cheng, S. S. (2002): Anitermitic activity of leaf essential oils and components from Cinnamonum osmophleum. - Journal of Agricultural Food Chemistry 50(5): 1389-1392.

[7] Cosimi, S., Rossi, E., Cioni, P. L., Canale, A. (2009): Bioactivity and quallitative analysis of some essential oil from Mediterrian plants against stored-product pests. Evaluation of repellency against Sitophilus zeamais Motschulsky, Cryptolestes ferrugineus Stephens and Tenebrio molitor L. - Journal of Stored Product Research 45: 125-132.

[8] DARP (2004): Database of arthropods resistance to pesticides. http://www.pesticideresistance.org/DB/index.html. Accessed on 25.05.2016.

[9] Dermauw, W., Wybouw, N., Rombauts, S., Menten, B., Vontas, J., Grbi, M., Clark, R. M., René Feyereisen, R., Van Leeuwen, T. (2013): A link between host plant adaptation and pesticide resistance in the polyphagous spider mite Tetranychus urticae. - PNAS 110(2): 113-122. www.pnas.org/cgi/doi/10.1073/pnas.1213214110.

[10] El-Zemity, S., Hussien, R., Saher, F., Ahmed, Z. (2006): Acaricidal activities of some essential oils and their monoterpenoidal constituents against house dust mite, Dermatophagoides pteronyssinus (Acari: Pyroglyphidae). - Journal of Zhejiang University Science B. 7: 957-962.

[11] Grotnitzky, J. A., Coats, J. R. (2002): QSAR evaluation of monoterpenoids insecticidal activity. - Journal of Agricultural Food Chemistry 50: 4576-4580.

[12] Isman, M. B. (2000): Plant essential oils for pest and disease management. - Crop Protection 19: 603-608.

[13] Isman, M. B. (2006): Botanical insecticides, deterrents, and repellents in modern agriculture and increasingly regulated world. - Annual Review Entomology 51: 45-56.

[14] Kawka, B., Tomczyk, A. (2002): Influence of extract from sage (Salvia officinalis) on some biological parameters of Tetranychusurticae Koch feeding on Algerian Ivy (Hederahelix variegate L.). - IOBC Bulletin 22: 96-100.

[15] Kizil, S. (2010): Determination of essential oil variations of Thymbra spicata var. spicata L. naturally growing in the wild flora of East Mediterranean and Southeastern Anatolia regions of Turkey. - Industrial Crops and Products 32: 593-600.

[16] Mansour, F., Ravid, U., Putievsky, E. (1986): Studies on the effects of essential oils isolated from 14 species of labiatae on the carmine spider mite, Tetranychus cinnabarinus. - Phytoparasitica 14: 137-142. 
[17] Miresmailli, S., Bradbury, R., Isman, M. B. (2006): Comparative toxicity of Rosmarinus officinalis L. essential oil and blends of its major constituents against Tetranychus urticae Koch (Acari: Tetranychidae) on two different host plants. - Pest Management Science 62: 366-371.

[18] Pascual-Villalobos, M. J., Robledo, A. (1998): Anti-insect activity of plant extracts from the Wild Flora in Southern Spain. Biochem. - Systematic Ecology 27: 1-10.

[19] Patrakar, R., Mansuriya, M., Priyanka, P. (2012): Phytochemical and pharmacological review on Laurus nobilis. - International Journal of Pharmaceutical and Chemical Sciences 1(2): 595-602.

[20] Rajkumar, S., Jebanesan, A. (2005): Oviposition deterrent and skin repellent activities of Solanum trilobatum leaf extract against the malarial vector Anopheles stephensi. Journal of Insect Science 5(15): 1-3.

[21] Tayoub, G., Abu Alnaser, A., Ghanem, I. (2012): Fumigant activity of leaf essential oil from Myrtus communis L. against the Khapra Beetle. - International Journal of Medicinal Aromatic Plants 2(11): 207-213.

[22] Tomczyk, A., Szymanska, M. (1995): Possibility of reduction of spider mite population by spraying with selected herb extracts. - Proceeding of 35th Scientific Session IOR, Part II, pp. 125-128.

[23] Traveset, A., Riera, N. R. E. (2001): Ecology of fruit-colour polymorphism in Myrtus communis and differential effects of birds and mammals on seed germination and seedling growth. - Journal of Ecology 89: 749-760.

[24] Tuni, I., Sahinkaya, S. (1998): Sensivity of two greenhouse pest to vapors essential oils. Experimental and Applied Entomology 86: 312-324.

[25] Tuttle, D. M., Baker, E. W. (1968): Spider Mites of Southwestern United States and a Revision of the Family Tetranychidae. - University of Arizona Press, Tucson, AZ.

[26] Van Pottelbelge, S., Van Leeuwen, T., Khajehali, J., Tirry, L. (2009): Genetic and biochemical anlysis of a laboratory-selected spirodiclofen-resistant strain of Tetranychus urticae Koch (Acari: Tetranychidae). - Pest Management Science 65: 358-366.

[27] Yorulmaz-Salman, S., Erbaş, S. (2014): Contact and repellency effects of Rosa damascena Mill. essential oil and its two major constituents against Tetranychus urticae Koch (Acari: Tetranychidae). - Türkiye Entomoloji Dergisi 38(4): 365-376.

[28] Zhang, Z. (2003): Mites of Greenhouses: Identification, Biology and Control. - CABI Publishing, Wallingford. 